\title{
Expression of glutathione S-transferases in normal and malignant pancreas: an immunohistochemical study
}

\author{
J D Collier, M K Bennett, A Hall, A R Cattan, R Lendrum, M F Bassendine
}

\begin{abstract}
The glutathione S-transferases (GSTs) are a family of detoxification and metabolising enzymes, which have been linked with the susceptibility of tissues to environmental carcinogens and resistance of tumours to chemotherapy. Environmental carcinogens have been implicated in the pathogenesis of pancreatic carcinoma, which is also a tumour characterised by marked chemotherapeutic drug resistance. In this study 26 pancreatic adenocarcinoma and 12 normal pancreatic samples were examined immunohistochemically for expression of pi (acidic), alpha (basic), and mu (neutral) GST. Fourteen $(54 \%)$ of the tumours expressed pi GST alone, two (8\%) expressed both pi and alpha GST, and two $(8 \%)$ showed immunoreactivity with alpha GST alone. In the normal pancreas the intralobular ducts and centroacinar cells expressed pi GST alone whereas the large ducts expressed both pi and alpha GST. The acinar cells showed immunoreactivity only with anti-alpha GST. Mu GST was not expressed by normal or malignant pancreas. Expression of pi GST by pancreatic carcinoma may be a marker of the malignant phenotype and be induced during neoplastic transformation. Alternatively it could possibly reflect cell of origin, suggesting that the tumour arises from the centroacinar cells or intralobular ducts, or both rather than the large ducts.

(Gut 1994; 35: 266-269)
\end{abstract}

Glutathione S-transferases (GSTs) are a multigene family of proteins that function as enzymes of detoxification. ${ }^{12}$ By catalysing the conjugation of potentially mutagenic electrophilic compounds with reduced glutathione cells may be protected from toxic damage. Inactivation of chemical carcinogens in this way may protect normal cells from insult as well as preventing already mutated cells from further damage and so maintaining the malignant phenotype. Some cytotoxic drugs are also metabolised by GSTs potentially leading to tumour drug resistance. ${ }^{3}$

Human cytosolic GST isoenzymes have been classified on the basis of functional and structural relations; the alpha class tends to have alkaline $(>8.0)$ isoelectric points while the $\mathrm{pH}$ values for the mu class are near neutral (7-8) and the pi class enzymes are acidic $(<7 \cdot 0) .^{1}$ An additional class of GSTs, designated theta, has recently been purified from human liver. ${ }^{4}$ The proteins within a class are probably members of a family that evolved from a single gene suggesting that each class provides an essential function to the survival of the whole organism.
Pi GSTs unlike the alpha enzymes, are expressed by a variety of human tumours ${ }^{35-10}$ and at higher values than corresponding normal tissues. ${ }^{56}$ Those tissues such as stomach and lung particularly exposed to environmental toxins have higher pi enzyme values suggesting a role in normal cellular protection. ${ }^{10}$ Both pi and alpha GSTs have been implicated in chemotherapeutic drug resistance. Adriamycin resistant MCF-7 breast carcinoma cells express higher values of pi GST than sensitive cells. ${ }^{13}$ In yeast, transfection with human alpha GST confers resistance to both adriamycin and chlorambucil. Resistance to the latter also occurs in cell lines expressing high values of alpha GST. ${ }^{14} 15$

Adenocarcinoma of the pancreas is a tumour with considerable intrinsic drug resistance and a resulting poor prognosis. Chemical carcinogens may be an important aetiological factor; this is suggested by an increased incidence in those working in the chemical industry and by the best animal model of the human tumour, hamster ductal adenocarcinoma, being induced by nitrosamines. ${ }^{16}{ }^{17}$ Recent studies have also shown a high incidence of mutations in the K-ras protooncogene at codon 12, which is consistent with carcinogen involvement. ${ }^{18}$ The GSTs, particularly pi, might therefore participate in the initiation or maintenance, or both, of the malignant phenotype as well as drug resistance and this is supported by an immunohistochemical study of GST in the hamster pancreas. ${ }^{19}$

We have therefore assessed the distribution of the three cytosolic GSTs immunohistochemically in human pancreatic adenocarcinoma and normal pancreas.

\section{Methods}

CASE MATERIAL

Formalin fixed paraffin embedded tissue from 25 cases of pancreatic carcinoma was used in this study. Clinical information was available on all patients from medical records. The male to female ratio was 12:15 with an age range of 33-78 years (median 61). Normal pancreas was available for analysis in a further five cases, the tissue having been obtained from Whipple's resections performed for diseases other than pancreatic carcinoma. Normal pancreas was also present adjacent to neoplastic tissue in $7 / 25$ of the cases studied.

PREPARATION OF ANTISERUM SAMPLES

Antiserum samples to the alpha, pi, and mu GST enzymes were raised in rabbits as previously described. ${ }^{20}$ Briefly, alpha and mu enzymes were
Cattan

Departments of Medicine
J D Collier
R Lendrum
M F Bassendine
and Pathology,
Freeman Hospital
M K Bennett
and Department of
Haematology,
Leukaemia Research
Fund Laboratories,
University of Newcastle
upon Tyne, Newcastle
upon Tyne
A Hall
A R Cattan
Correspondence to:
Dr M F Bassendine,
Department of Medicine,
The Medical School,
University of Newcastle upon
Tyne, Newcastle upon Tyne
NE2 4HH.
Accepted for publication
28 June 1993


purified from human necropsy liver and pi GST from the spleen of a patient with chronic lymphocytic leukaemia. These antigens were homologous as judged by SDS-PAGE and isoelectric focusing. Two hundred $\mu \mathrm{g}$ of protein in Freund's complete adjuvant was injected into male New Zealand white rabbits initially and subsequently monthly in Freund's incomplete adjuvant. The antiserum samples specificity was assessed using an enzyme linked immunosorbent assay (ELISA) technique and western blotting. ${ }^{20}$

\section{IMMUNOHISTOCHEMISTRY}

Three $\mu \mathrm{m}$ paraffin wax embedded sections were cut from tissue blocks, dewaxed in xylene, and rehydrated through graded alcohols. Endogenous peroxidase was blocked with $0.5 \%$ hydrogen peroxide in water for 10 minutes. Sections were incubated with the primary polyclonal antibodies pi GST (1/400), alpha GST $(1 / 500)$, and $\mathrm{mu}$ GST $(1 / 200)$ overnight at $4^{\circ} \mathrm{C}$. Immunohistochemical staining was carried out using an indirect immunoperoxidase method and $3,3^{\prime}$ diaminobenzidine (Sigma) was used as

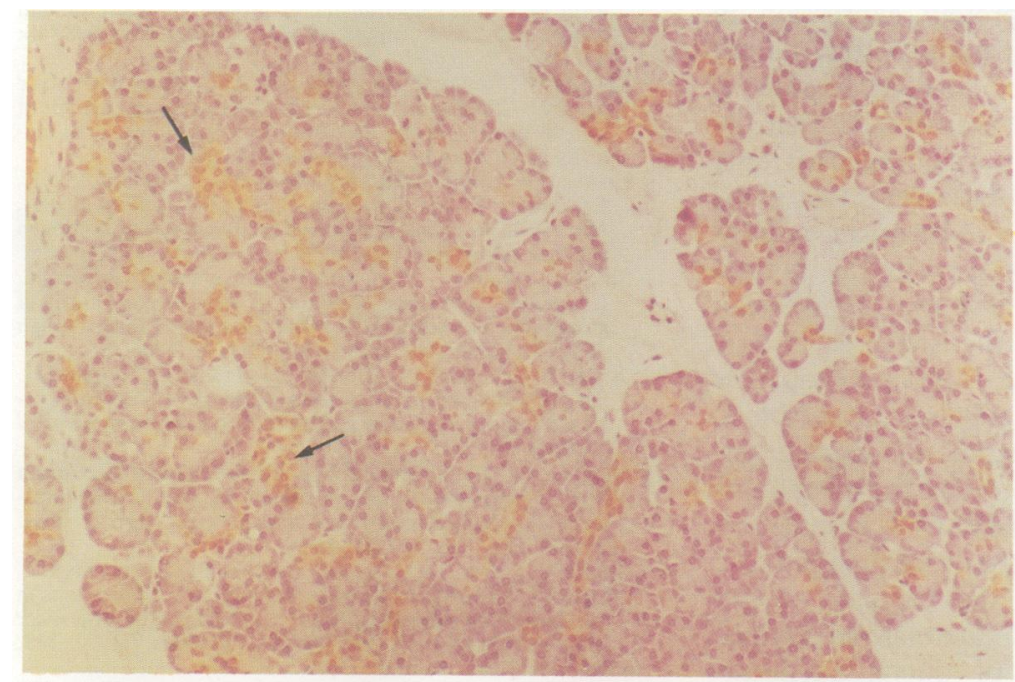

Figure 1: (upper): staining with anti-pi GST confined to intralobular ducts and centroacinar cells (arrowed) within normal pancreas (original magnification $\times 128) ;($ lower): strong cytoplasmic immunoreactivity with polyclonal antibody to alpha GST confined to exocrine acini $(A)$ and large pancreatic ducts $(D)$. No staining is seen in the islets of Langerhan $(I)$ (original magnification $\times 128$ ).

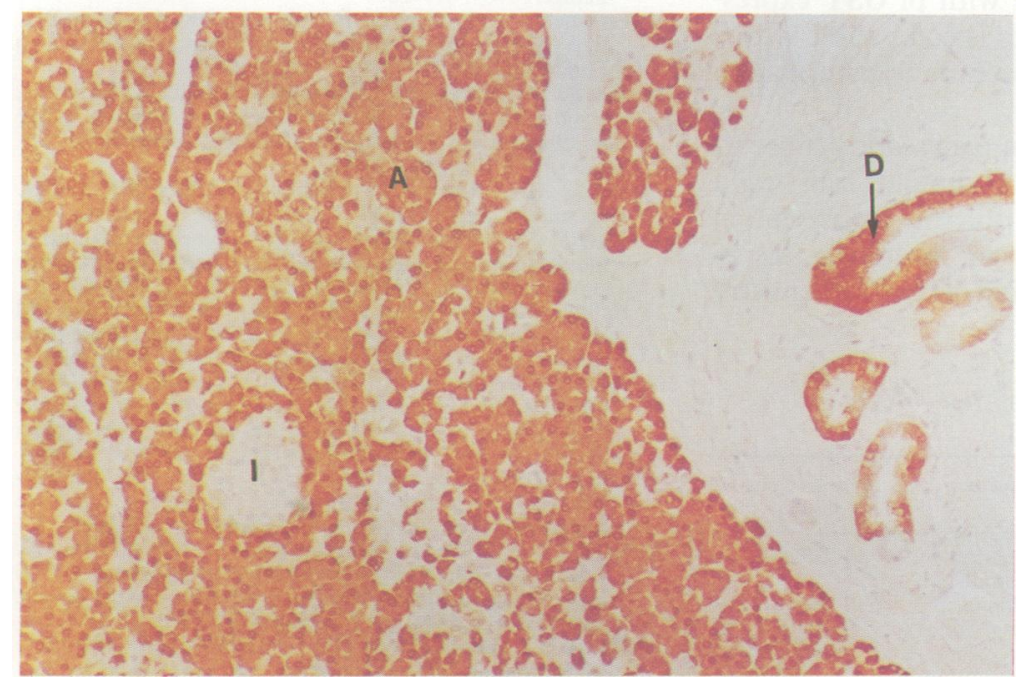

the chromagen. The sections were counterstained with haematoxylin, dehydrated, and mounted. Human kidney was used as a positive control for alpha and pi GST.

\section{Results}

\section{NORMAL PANCREAS}

The centroacinar cells, intralobular ducts, and larger ducts stained with the pi GST antibody but there was no staining of the acinar tissue or islets (Fig 1 upper panel). Conversely alpha GT was detected only in the acinar cells and larger ducts (Figl lower panel). The acini staining was not uniform but the centoacinar cells and intralobular ducts seemed consistently free of immunoreactivity. There was no immunoreactivity with the mu GST within the pancreas. All staining was confined to the cytoplasm. The pattern of staining described above was also seen in the normal pancreas present adjacent to tumour tissue.

\section{DUCTAL ADENOCARCINOMA}

Sixteen of $26(61 \%)$ cases of tumour showed immunoreactivity with pi GST (Fig 2). The staining was predominantly cytoplasmic with only occasional additional nuclear staining. The extent of staining was variable affecting over $50 \%$ of the tumour cells in seven cases with very focal staining in four tumours. When immunoreactivity occurred it tended to affect groups of cells suggesting clonality. Only 4/26 (15\%) tumours expressed alpha GST, which was weak and focal. In two of these the tumour had also stained with the pi GST. Mu GST was not expressed by any of the tumours (Table).

\section{Discussion}

The expression of pi GST in most pancreatic adenocarcinoma is in agreement with that seen in a wide variety of other tumours including colon, lung, cervix, and brain. ${ }^{821} 22$ Overexpression of pi GST in malignant tissue compared with corresponding normal tissue combined with its expression in preneoplastic and neoplastic lesions in the cervix $^{11}$ and colon $^{23}$ have been used to argue that pi GST is a 'tumour marker'. ${ }^{21}$ It is not a universal tumour marker, however, in that some tumours (for example, liver ${ }^{24}$ ) do not express pi GST. In addition pi GST has been shown to be induced in other disease states such as alcoholic hepatitis $^{25}$ so that overexpression cannot be equated solely with neoplastic transformation.

Of equal interest is the consistent absence of immunoreactivity for alpha GST in most pancreatic tumours. This has also been reported in human hepatocellular carcinoma, breast carcinoma, rat chemically induced preneoplastic liver nodules, and poorly differentiated cell lines. ${ }^{24-28} \mathrm{Mu}$ GST, unlike pi and alpha, is not expressed by almost half of the normal population because of a genetic polymorphism. ${ }^{23}$ The biological significance of our findings in pancreatic cancer awaits a greater understanding of the normal cellular function of the different isoenzymes; thus it may be that a reduced level of 


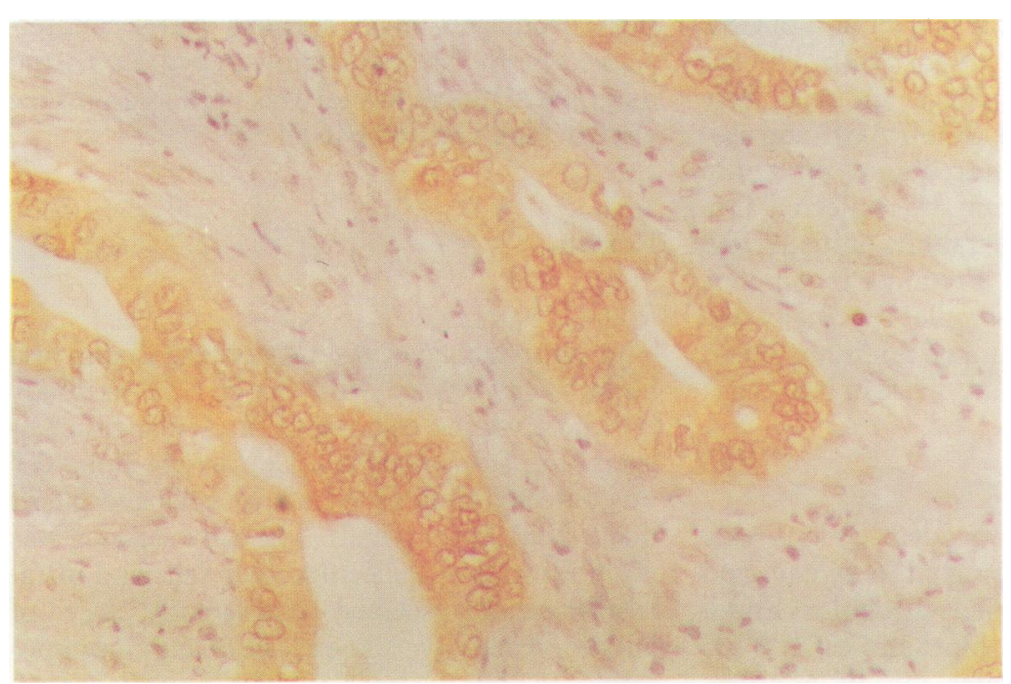

Figure 2:

Strong cytoplasmic immunoreactivity with polyclonal antibody to $\mathrm{pi}$ $G S T$ in a well differentiated pancreatic carcinoma (original magnification $\times 320)$. of the different classes of GST and the origin of the pancreatic tumour cell are needed to evaluate this hypothesis further.

J D Collier is supported by a grant from the Newcastle District Health Authority research committee. We would like to thank Mr Venables for his help with this study.

The data described in this paper has been previously published in abstract form in Gut 1992; 33 (suppl 2): S23.

1 Boyer TD. The glutathione s-transferases: an update. Hepatology 1989; 9: 486-96.

2 Ketterer B. Protective role of glutathione and glutathione transferases in mutagenesis and carcinogenesis. Mutat Res 1988; 202: 343-61.

3 Waxman DJ. Glutathione s-transferases: role in alkylating agent resistance and possible target for modulation chemotherapy - a review. Cancer Res 1990; 50: 6449-54.

4 Meyer DJ, Coles B, Pemble SE, Gilmore KS, Fraser GM, Ketterer B. Theta, a new class of glutathione transferase purified from rat and man. Biochem $\mathcal{f} 1991$; 274: 409-14.

5 Moscow JA, Fairchild CR, Madden MJ, Ransom DT, Wieand HS, O'Brien EE, et al. Expression of anionic glutathione HS, O'Brien EE, et al. Expression of anionic glutathione S-transferase and P-glycoprotein genes

6 Kano T, Sakai M, Muramatsu M. Structure and expression of a human class $\pi$ glutathione $S$-transferase messenger RNA Cancer Res 1987; 47: 5626-30.

7 Soma Y, Satoh K, Sato K. Purification and subunit-structural and immunological characterization of five glutathione- $S$ transferases in human liver, and the acidic form as a hepatic tumor marker. Biochim Biophys Acta 1986; 869: 247-58.

8 Shea TC, Kelley SL, Henner WD. Identification of an anionic form of glutathione transferase present in many human tumors and human tumor cell lines. Cancer Res 1988; 48 : 527-33.

9 Randall BJ, Angus B, Akiba R, Hall A, Cattan AR, Proctor $\mathrm{SJ}$, et al. Glutathione s-transferase (placental) as a marker of transformation in the human cervix uteri: an immunotransformation in the human cervix uteri: an
histochemical study. $B r f$ Cancer $1990 ; 62: 614-8$.

10 Howie AF, Miller WR, Hawkins RA, Hutchinson AR Beckett GJ. Expression of glutathione s-transferase $B_{1}, B_{2}$, $\mathrm{Mu}$ and $\mathrm{Pi}$ in breast cancer and their relation to oestrogen receptor status. $\mathrm{BrF}$ Cancer 1989; 60: 834-7.

11 Shiratori Y, Soma Y, Maruyama H, Sato S, Takono A, Sato K Immunohistochemical detection of the placental form of glutathione S-transferase in dysplastic and neoplastic human uterine cervix lesions. Cancer Res 1987; 47: 6806-9.

12 Terrier P, Townsend AJ, Coindre JM, Triche TJ, Cowan KH. An immunohistochemical study of pi class glutathione stransferase expression in normal human tissue. Am $\mathcal{F}$ Pathol 1990; 137: 845-52.

13 Batist G, Tulpule A, Sinha BK, Katki AG, Myers CE, Cowan $\mathrm{KH}$. Overexpression of a novel anionic glutathione transferase in multidrug-resistant human breast cancer cells. ferase in multidrug-resistant hum

14 Black SM, Beggs JD, Hayes JD, Bartoszck A, Muramatsu M, Sakai M. Expression of human glutathione S-transferases in Saccharomyces cervisiae confers resistance to the anticancer drugs adriamycin and chlorambucil. Biochem $\mathcal{F} 1990 ; 268$ : 309-15.

15 Lewis AD, Hickson JD, Robson CN, Harris AL, Hayes JD Griffiths SA, et al. Amplification and increased expression of alpha class glutathione S-transferases-encoding genes associated with resistance to nitrogen mustards. Proc Nat Acad Sci USA 1988; 85: 8511-5.

16 Fontham E, Correson P, Colin I. Epidemiology of cancer of the pancreas. In: Howard IM, Jordon GL, Reber HA, eds. the pancreas. In: Howard IM, Jordon GL, Reber HA, eds Surgical disease of the

17 Longnecker DS, Wiebkia P, Schaeffer BK, Roebuck RD. Experimental carcinogenesis in the pancreas. Int Rev Exp Pathol 1984; 24: 177-229.

18 Shibata D, Almoguera C, Forrester K, Dunitz J, Martin SE, Cosgrove $M M$, et al. Detection of $c-K$-ras mutations in fine needle aspirates from human pancreatic adenocarcinomas. Cancer Res 1990; 50: 1279-83.

19 Moore MA, Bannasch P, Satoh T, Hacker HJ, Ito N. Immunohistochemically demonstrated increase in glutathione $\mathrm{S}$-transferase species in propylnitrosamine induced focal proliferative and neoplastic syrian hamste pancreatic lesions. Virchows Arch [B] 1987; 52: 479-88.

20 Hall A, Foster S, Proctor SJ, Cattan AR. Purification and characterization of a pi class glutathione $S$-transferase from characterization of a pi class glutathione S-transferase from

21 Kantor RRS, Giardina SL, Bartolazzi A, Townsend AJ, Myers $\mathrm{CE}$, Cowan KH, et al. Monoclonal antibodies to glutathione CE, Cowan KH, et al. Monocional antibodies to glutathione S-transferase $\pi$-immunohistochemical analysis of
tissues and cancers. Int $\mathcal{F}$ Cancer 1991; 47: 193-201.

Expression of glutathione S-transferase (GST) isoenzymes in normal and malignant pancreas

\begin{tabular}{lll}
\hline GST isoenzyme & $\begin{array}{l}\text { Normal pancreas } \\
(n=12)\end{array}$ & $\begin{array}{l}\text { Adenocarcinoma } \\
(n=26)\end{array}$ \\
\hline $\mathrm{Pi}$ & $\begin{array}{l}\text { Centroacinar cells } \\
\text { Intralobular ducts }\end{array}$ & $14(54 \%)$ \\
Alpha & Acinar cells & $2(8 \%)$ \\
$\mathrm{Pi}$ and alpha & Large ducts & $2(8 \%)$ \\
$\mathrm{Mu}$ & - & - \\
\hline
\end{tabular}

22 Campbell JAH, Corrigall AV, Guy A, Kirsch RE. Immunohistological localization of alpha, mu and pi class glutathione 67: 1608-13.

23 Kodate C, Fukushi A, Narita T, Kudo H, Soma Y, Sato K Human placental form of glutathione $S$-transferase (GST- $\pi$ ) as a new immunohistochemical marker for human colonic carcinoma. Fpn $\mathcal{F}$ Cancer Res 1986; 77: 226-9.

24 Hayes PC, May L, Hayes JD, Harrison DJ. Glutathione S transferases in human liver cancer. Gut 1991; 32: 1546-9. 
25 Harrison DJ, May L, Hayes PC, Hague MM, Hayes JD. Glutathione S-transferases in alcoholic liver disease. $G u t$ 1990; 31: 909-12.

26 Shea TC, Claflin G, Comstock KE, Sanderson BJS, Burstein NA, Keenon EJ, et al. Glutathione transferase activity and isoenzyme composition in primary human breast cancers. Cancer Res 1990; 50: 6848-53.

27 Jensson H, Eriksson LC, Mannervik B. Selective expression of glutathione transferase isoenzymes in chemically induced glutathione transferase isoenzymes in chemically induced preneop

28 Kitahara A, Satoh K, Nishimura K, Ishikawa T, Ruike K, Sato $\mathrm{K}$, et al. Changes in molecular forms of rat hepatic glutathione s-transferase during chemical hepatocarcinogenesis. Cancer Res 1984; 44: 2698-703.

29 Hayes PC, Harrison DJ. Immunochemical analysis of pancreas and gastrointestinal tract in man. In: Hayes JD, Pickett CB, Mantle TJ, eds. Glutatione S-transferases and drug resistance. London: Taylor and Francis, 1990: 441550

30 Pour PM. Mechanism of pseudoductular (tubular) formation during pancreatic carcinogenesis in the hamster model. An electron-microscopic and immunohistochemical study. Am f Pathol 1988; 130: 335-44.

31 Pour PM. Cell differentiation during pancreatic carcinogenesis. Scand $\mathcal{F}$ Gastroenterol 1988; 23: 123-30. 